\title{
Literature review of the use of birds as pets in Latin- America, with a detailed perspective on Mexico
}

\author{
Blanca Roldán-Claràl*, Xavier López-Medellín², lleana Espejel', Evarista Arellano'
}

\begin{abstract}
A large amount of birds are harvested from the natural environment for the pet market. This trade is a conservation issue and an economic income for many people. Though bird trade is common in Latin America there are few published studies. Therefore, we reviewed available literature to understand the background of this topic and to identify future relevant research topics. We collected, summarized and discussed literature about bird use as pets in Latin America, with a detailed approach in Mexico. We searched by keywords in web search engines and constructed a database of 159 documents. Brazil was identified as one of the main countries with research on birds use. Most of the papers focused on parrots (35\%) and were conducted at a local geographical level (71\%). Less than half of the papers (39\%) are focused on the general use of birds, $54 \%$ on the use as pets and $7 \%$ on other uses. In Mexico, $73 \%$ of the information is "gray literature", mainly congress abstracts. This literature review shows that wildlife use in general and wild birds use as pets in particular are common in Latin America. We bring to light that most of the information is not found in peer review journals and contains only lists of useful birds. Finally, we found that research on social organization and on the perceptions of the main actors is scarce, so we suggest more research in this direction in order to implement better management policies.
\end{abstract}

Keywords: Bird trade, Bird use, Ethnoornithology, Parrots, Wildlife

\section{INTRODUCTION}

Every year in Latin America, many animals and plants are removed alive from the wilderness to be traded. Among the animals and plants that are traded in the world, birds are likely to be the most exploited (Iñigo-Elias \& Ramos 1991), particularly song (S) and ornamental (O) birds ( $S$ and $\mathrm{O}$ birds). These $\mathrm{S}$ and $\mathrm{O}$ birds include the families Psittacidae (parrots, parakeets, cockatoos and macaws), Cardinalidae (cardinals, grosbeaks, and goldfinches), and Emberizidae (sparrows, and towhees), although other families are also traded (Parulidae, Mimidae and Corvidae) (LópezMedellín 2003). These birds are kept in captivity as pets (Iñigo-Elias \& Ramos 1991; Thomsen et al. 1991) because of their beauty, their bright colors, their melodic songs, their attachment to humans, and because they can mimic the sound of some words (Gobbi et al. 1996; López-Medellín 2003). There are other reasons for keeping birds in captivity, e.g., to use them as a hunting tool (falconry) as in the case of the birds of prey (IñigoElias 1983). In addition, bird products and sub-

1 Universidad Autónoma de Baja California (UABC), Carretera Transpeninsular Ensenada-Tijuana \# 3917 Fraccionamiento Playitas. C.P: 22860, Ensenada, Baja California, México

* Corresponding author: E-mail address: blancamar@gmail.com

2 Centro de Investigación en Biodiversidad y Conservación, Universidad Autónoma del Estado de Morelos, Av. Universidad 1001. Col. Chamilpa. C.P: 62209, Cuernavaca, Morelos, México 
products are used for the production of amulets and/or medicines (Gómez Álvarez \& Reyes Gómez 2010). Both bird habitat destruction and bird trade are among the main threats to wild birds worldwide (Reuter \& Mosig 2010). Only a small fraction of the birds that are traded comes from captive breeding, which is typically exemplified by budgerigars (Melopsittacus undulatus), cockatiels (Nymphicus hollandicus), canaries (Serinus sp.), and lovebirds (Agapornis sp.) (Bird Trade SC of the AOU Conservation Cmte 1991).

In particular, the Psittacidae family (commonly known as "parrots", which include parrots sensu stricto, parakeets, and macaws) are strongly affected by exploitation and trade (Cantú Guzmán et al. 2007; Wright et al. 2001) despite being endangered species (Collar 1992, NOM-059; DOF 2010) because they are especially popular as pets and fetch a high price in the market (Gobbi et al. 1996; Wright et al. 2001). One of the most emblematic and discussed exploitations has been that of the parrots in Mexico, and this topic has received significant attention in recent years because this group of birds is very charismatic and is highly valued in the market (Iñigo-Elias \& Ramos 1991). However, parrots occupy the second position in bird trade after the passerines (Thomsen et al. 1991), from which many wild birds are captured to be traded in Latin America and in Mexico in particular (López-Medellín 2003; Thomsen et al. 1991). Although only a small fraction of the passerines is currently protected for their conservation, their situation requires attention.

There are papers related to the bird trade at an international level (e.g. Bush et al. 2014), and very few with relative approaches to continental level (e.g. Abensperg-Traun 2009; Alacs \& Georges 2008) but none in Latin America as a whole. Moreover, no review papers related to bird keeping were been found for Latin America. In Mexico, there is one review known that is related to the ethnozoology research as a whole (Argueta Villamar et al. 2012), but not exclusively to the ethnoornitology or about the bird keeping on specific, even though the use of bids as pets in Mexico is an ancestral (Sahagún 1969) and a very popular activity (López-Medellín \& Iñigo-Elias 2009). Due to the lack of studies that analyze the state of the art in bird exploitation in
Latin America, a bibliographic review based on the available information on this matter is presented in this paper, in order to summarize, compile, analyze, and discuss the current knowledge on the exploitation of song and ornamental birds in Latin America with particular emphasis on Mexico. We anticipated that the largest proportion of scientific studies on this matter would be focused on the exploitation of parrots, which might result from to the fact that this group of birds is considered to be more vulnerable, because parrots exhibit a low birth rate and are culturally appreciated at both international and local levels. All these features likely favor the development of a greater number of studies focused on them. However, these circumstances can promote a careless attitude towards other groups of birds that, although are not endangered, still are equally important and are being affected by this practice.

\section{METHODS}

To compile the information, an automatized exploration was performed from February to July 2014 through the following web search engines: Springerlink, Science Direct, Elsevier, EBSCO, Scopus, Science, Google Scholar, SORA (Searchable Ornithological Research Archive), OWL (Ornithological Worldwide Literature), Birdnet and REDALYC (Red de Revistas Científicas de América Latina y el Caribe, España y Portugal -The Scientific Journals Network for Latin America, the Caribbean, Spain and Portugal). We used keywords in the search sections title, keywords, and summary. The languages used in the search were English, Spanish and Portuguese.

The keywords that were applied were the following (its meaning in three languages): trade, wildlife trade, pet trade, illegal trade, internal trade, domestic trade commercialization, pets, songbirds, ornamental birds, wild fauna exploitation, traffic, illegal traffic market, exploitation, harvest, exploitation rate, poachers unions, pet shops, caged birds, and finally Wildlife Conservation Management Unit (known in Mexico as UMA by its Spanish acronym), that are part of an initiative of the Mexican government to registering ranches 
and private installations; they operate through a management plan approved by the State Wildlife Office -Dirección General de Vida Silvestre, DGVS, for its name and initials in Spanish (Valdez et al. 2006).

The documents' titles obtained by the web search were checked to ensure that they largely addressed the utilization and exploitation of $S$ and $\mathrm{O}$ birds and thus avoided the inclusion of papers that address other types of wild fauna such as mammals or birds of prey. However, those papers that, despite dealing with fauna or even with wildlife, comprised a section on the exploitation of $S$ and $O$ birds were also included. Papers that focused solely on the international trade of wildlife, on the transmission of diseases resulting from fauna trafficking, and on the introduction of invasive species, were excluded because they were considered to address topics that are out of the scope of this review.

Afterwards, and with the aim of developing a more detailed analysis of the subject matter in Mexico, a second search was performed that comprised the following steps:

(1) A search (on the 26th of April, 2012) through the digital thesis published by both the National Autonomous University of Mexico (UNAM by its Spanish acronym) and the National Polytechnic Institute (IPN by its Spanish acronym). Only those thesis whose abstracts were available were considered.

(2) A web search through the congress abstracts of eight years (1995-2012) of the National Ornithological Congress and Symposium from the Mexican Ornithological Society, (NPO, by its Spanish acronym); four years (2008 - 2011) of the Congress for the Study and Conservation of Birds in Mexico (CECAM, by its Spanish acronym), from the Society for the Study and Conservation of birds in Mexico, (CIPAMEX, by its Spanish acronym); and one year (2007) from the Mexican Congress of Ethnobiology from the Mexican Ethnobiology Association (AEM, by its Spanish acronym). The titles of all communications and posters were read, and those studies that focused on the utilization of birds in past centuries or on the magical and religious uses of birds were discarded as well. In addition, those abstracts dealing with hunting that did not consider $\mathrm{S}$ or $\mathrm{O}$ birds were also discarded as well. Intrigued by the vague information we got from this source, we sent emails to the authors of the selected abstracts to ask them for the printed or the digital versions of their publications.

(3) A complete search was done through the 13 published years (2001 - 2014) of the main Mexican journals regarding zoology: Revista Mexicana Etnobiología, Acta Zoológica Mexicana (new series), and another web search was done in one of the most important databases in wildlife: the National Institute of Ecology (INE, for its Spanish acronym).

(4) Because key collaborators and informants recommended that we checked some papers that were not available on the internet, an e-mail was sent asking for the corresponding information to the Ornitológica de Mexico [Mexican Ornithological Society] and CIPAMEX groups.

The variables used to classify the studies were the following:

- Country where the study was performed

- Language

- Type of trade (national, cross-border or international).

- Traded resource (wildlife, wild fauna, wild birds, song and ornamental birds, and parrots, among other birds).

- Type of utilization: (1) General: in which birds are used not only as pets but also as food, medicine, ornament, etc. (2) Ornamental or as pets: in which birds are used solely as pets or as ornamental birds kept alive. (3) Other uses: in which birds are used but not as pets or as ornamental birds.

- Scope of the study: local, national or international. A local scope takes into account those studies whose area of study is smaller than an entire country (state, district, and protected natural area, among others). A national scope includes those studies in which the total surface of a country is considered. Finally, an international scope includes those studies performed in two or more Latin American countries. 


\section{RESULTS AND DISCUSSION}

A total of 159 documents were selected for this review, which belonged to six categories: peer-reviewed papers, reports, laws, congress abstracts, thesis, and others. From this total, $45 \%$ were peer-reviewed papers, and $55 \%$ were grey literature (thesis, reports, congresses abstracts, books, reports, legislative, governmental and divulgation documents). Thus, we found that there is an important amount of material versed on the subject matter that has not been published in peer-reviewed journals. We think it is necessary to strengthen research policy in Latin American countries and to motivate academics, students, and resource managers to publish their results in peer-reviewed journals so that the gathered information does not remain as grey literature and is lost in time. Although gray literature in developing countries is often used as data bases for management decisions (Lacanilao 1997) in general, grey literature is not reviewed at all (Weintraub 2000). Besides, the quality of all studies increases when published in peer-reviewed journals (Lacanilao 1997).

Most of the peer-reviewed papers were researches performed in Brazil and Mexico (mention should be made to our biased search towards Mexico). Altogether, 26 papers addressed the subject matter in Brazil, 25 in Mexico, three in Venezuela and Colombia, two in Peru and Bolivia, and one in Panama, Costa Rica and Argentina. In addition, there were seven studies that took place in various countries or that were not linked to a particular geographical area. The prevalence of studies in Brazil and Mexico may be due to the combination of three different issues: the great extension of these two countries, their high biodiversity (Brazil and Mexico are megadiverse countries), and their economic growth (Sarukhan 2012; Scarano et al. 2012). In particular, Brazil invests intensively in science and has a high scientific production at the international level (Regalado 2010; Scarano 2007). Additionally, this country is a leader in knowledge production in a variety of areas (Albuquerque 2013), and the most interesting topics for Brazilian scientists are ecology, environmental sciences, fauna, and flora (Scarano 2007).

When all of the documents were examined as a whole, Spanish was the most common language, but when only the scientific papers published in peer-reviewed journals were considered, English was the most frequently used language (Figure 1). This relationship is obvious because English has become the language most commonly used in science communication at the international level (Quijada 2008).

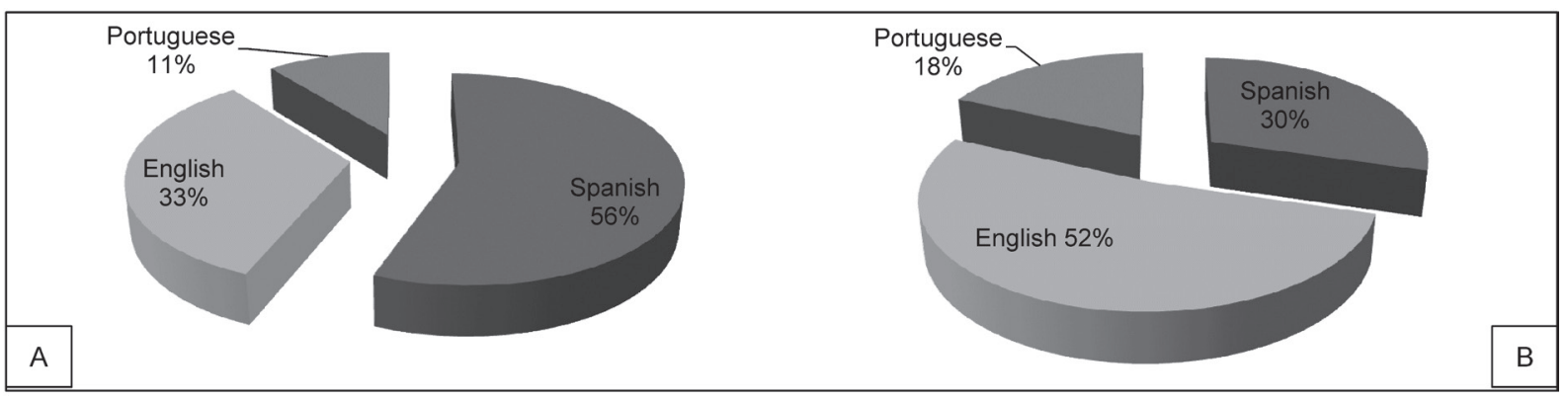

Figure 1. Proportion of languages in all the documents analyzed (A) and in peer-reviewed journals (B).

The most representative subjects of study among the selected documents were wild birds, followed by parrots and similar taxa (Figure 2A), and the most representative subjects of study in scientific papers were parrots, followed by other wild birds (Figure 2B). This observation might be because the scientific community has a greater interest in studying the exploitation of parrots. Thus, there are specific congresses and symposia about parrots, such as the Parrot International Congress, which takes place every four years, or the yearly Mesoamerican Congress 
on the Conservation of Psittaciformes. In addition, parrots and similar taxa are more interesting for the community dedicated to the conservation of wildlife (e.g. Juniper 2002) because a greater number of their species are protected by national or international laws and because they are considered very charismatic. These reasons might suggest that larger amounts of money are invested in projects that address this group of birds. Wild fauna topic was important as well (Figure $2 \mathrm{~A}$ and $2 B$ ), suggesting that a great deal of the existent information on the utilization of birds is included in documents in which wild fauna is considered as a whole.

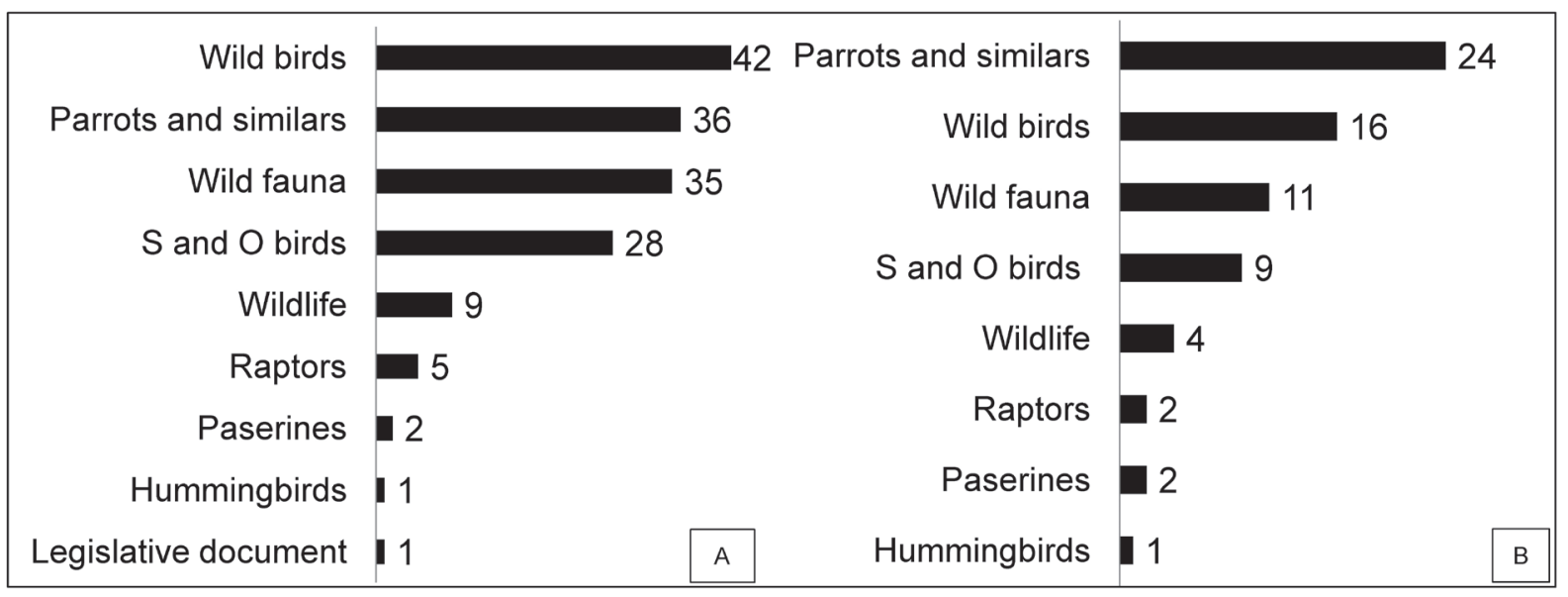

Figure 2. (A) Number of documents depending on the subject of study and (B) number of papers depending on the subject of study.

According to the uses of the exploited resources, the most representative in all document types, as well as in the scientific papers specifically, is the "general use" (Figure 3). This is because most of the documents describe how resources are used, and exploited birds are used as pets, food, or might have medicinal or folk uses, among others. For example, in a study by Bezerra and collaborators
(2011), the bird species used in the rural communities of the district of Serra Negra do Norte, Brazil are identified, and their uses are determined. The authors observed that in this particular location, birds are used in different ways, although they are mostly used as pets. Thus, among the collected documents, there is little specific information about song or ornamental birds.

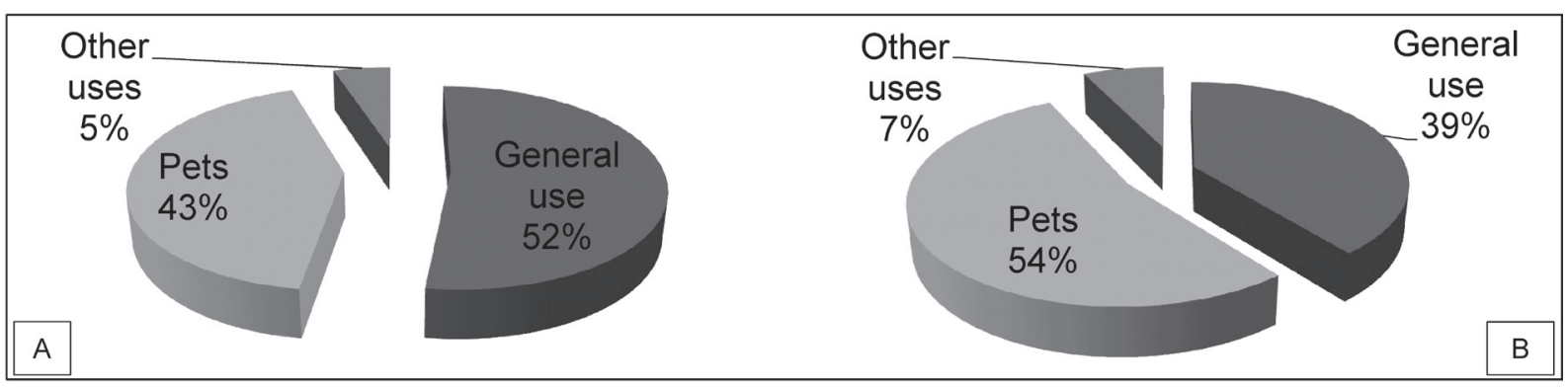

Figure 3. Average usage rate in the whole of the documents obtained (A) and only in per-reviewed journals (B).

We analyzed how this pass-time the research in the 41 Latin American published papers is being proposed (Table 1) without taking into account the information contained in the Mexican published papers. We found that $63 \%$ of these studies provide lists of the traded species and/or the numbers of 
traded specimens (e.g. Rocha et al. 2006). Five studies provided information only on the utilized species, although 20 provided also economic, social, and/or ecological information (e.g. Alves et al. 2010). In 59\% of the papers, a combination of approaches or disciplines were applied, reflecting the interdisciplinary nature of the studies. In some of the studies, the capture techniques applied at the locations where the specimens were caught (e.g. Bezerra et al. 2012) and focused on the corresponding bird maintenance techniques (e.g. Licarião 2013). In Gama \& Sassi (2008) study, birdtrading techniques were explained, and in Licarião (2013) and Barbosa et al. (2010), the authors explain how the users obtained the traded specimens. Additionally, information on the prices, the uses, and on the Use-Value (UV, the number of times that a species is cited as used by the interviewees divided by the number of informers asked (Phillips et al. 1994) of the traded species is also provided. At the social level, the socioeconomic and cultural characteristics of the actors, usually the poachers and the traders, are studied (e.g. Alves et al. 2013). In three papers, the organization of the species exploitation is described, and in five studies, the perception of the actors is considered (e.g. Onofri Saiki et al. 2009). In some cases, certain ecological aspects of the utilized populations are also discussed, such as the relative abundance, density, and reproductive success. Marín-Espinoza et al. (2011) report the richness and bird presence frequency at the studied markets. Other ecological or biological issues are also considered in some studies: the traded species distribution (Desenne \& Strahl 1991), age and origin of the traded specimens (Herrera \& Hennessey 2008), the birds' condition at the markets (Regueira \& Bernard 2012), diseases types observed in confiscated birds (Godoy \& Matushima 2010), genetic relationship between parrots of the same species confiscated (Fernandes \& Caparroz 2013) and the relationship between parrot trade and the occurrence of hypovitaminosis A (Weston \& Memon 2009). In five papers, the implications of the utilization of these species for their conservation are considered (e.g. BriceñoLinares et al. 2011; Fernandes-Ferreira et al. 2012). Two of the studies included a review about parrot trading in Latin America (Weston \& Memon 2009) and about birds in Brazil (Alves et al. 2013). In ten papers, topics other than those mentioned above were considered. For example, Marín-Espinosa and collaborators (2011) obtained the specific offer rate of the birds found at the monitored markets. In the work presented by Desenne and Strahl (1991), the techniques for parrot trading in Venezuela were considered. Herrera and Hennesse (2008) provided information on the parrots' destination in Bolivia. Finally, two opposite visions concerning bird trade for the pet market were compared. Beissinger and Bucher (1992) mention that the development of sustainable parrot exploitation is possible and propose a conservative model for harvesting these birds. On the other hand, the Subcommittee on Bird Trade of The American Ornithologists' Union Conservation Committee (1991) argues the need for a moratorium on parrot trading. 
Table 1. Information extracted from 41 papers, excluding those that contained data gathered in Mexico.

\begin{tabular}{|c|c|c|c|}
\hline$\#$ & $\begin{array}{l}\text { Information } \\
\text { Type }\end{array}$ & Information provided by the paper & $\begin{array}{c}\text { Number of } \\
\text { papers }\end{array}$ \\
\hline 1 & List & Lists of species and/or numbers of specimens & 26 \\
\hline 2 & Technical & Poaching techniques & 7 \\
\hline 3 & & Locations where the species were poached & 4 \\
\hline 4 & & Trading techniques & 1 \\
\hline 5 & & How the users obtained the specimens & 2 \\
\hline 6 & & Maintenance techniques & 6 \\
\hline 7 & Economic & Utilization of the species & 9 \\
\hline 8 & & Use-Value (UV) & 6 \\
\hline 9 & & Prices of the species & 5 \\
\hline 10 & Social & Socioeconomic or cultural characteristics of the actors & 7 \\
\hline 11 & & Actors organization & 3 \\
\hline 12 & & Actors perception & 5 \\
\hline 13 & Ecological & Resource abundance & 5 \\
\hline 14 & & Reproductive success & 3 \\
\hline 15 & & Other ecological or biological data & 9 \\
\hline 16 & & Implications for conservation & 5 \\
\hline 17 & Review & Review paper & 2 \\
\hline 18 & Other & Other type of information & 10 \\
\hline
\end{tabular}

We may also comment that two main techniques were used to obtain the results presented in these studies: interview and observation. However, many other research techniques were also detected, as shown in Table 2. We may conclude that research on the use of live birds for pet trade in Latin America predominantly employs techniques that belong to the social sciences.

Table 2. Techniques used in the analyzed Latin American papers, excluding those that contained data gathered in Mexico. A paper may use more than one technique.

\begin{tabular}{|c|c|c|}
\hline Type of approach & Technique & $\begin{array}{c}\text { Number of papers that use } \\
\text { this Technique }\end{array}$ \\
\hline+ Social & Interviews or surveys & 20 \\
\hline \multirow{12}{*}{$\uparrow$} & Participative workshops & 3 \\
\hline & Environmental education & 2 \\
\hline & Participant observation or direct observation & 14 \\
\hline & Documental investigation & 9 \\
\hline & Permit analyses & 2 \\
\hline & Analysis of seizures or rescues & 4 \\
\hline & Hidden filming & 1 \\
\hline & Use-Value (UV) & 5 \\
\hline & Geographic information systems & 2 \\
\hline & Mathematical models or formula & 3 \\
\hline & Microbiological methods & 2 \\
\hline & Transect sampling of the birds' populations & 4 \\
\hline$\downarrow$ & Nest monitoring & 3 \\
\hline + Biological & Assisted reproduction & 1 \\
\hline
\end{tabular}


Most of the studies were performed at local geographical level: half $(52 \%)$ of the studies, if all the documents are considered as a whole; and $72 \%$ of the studies, if only the scientific papers are considered (Figure 4A). We suppose that it is so because local studies are cheaper and easier to accomplish.

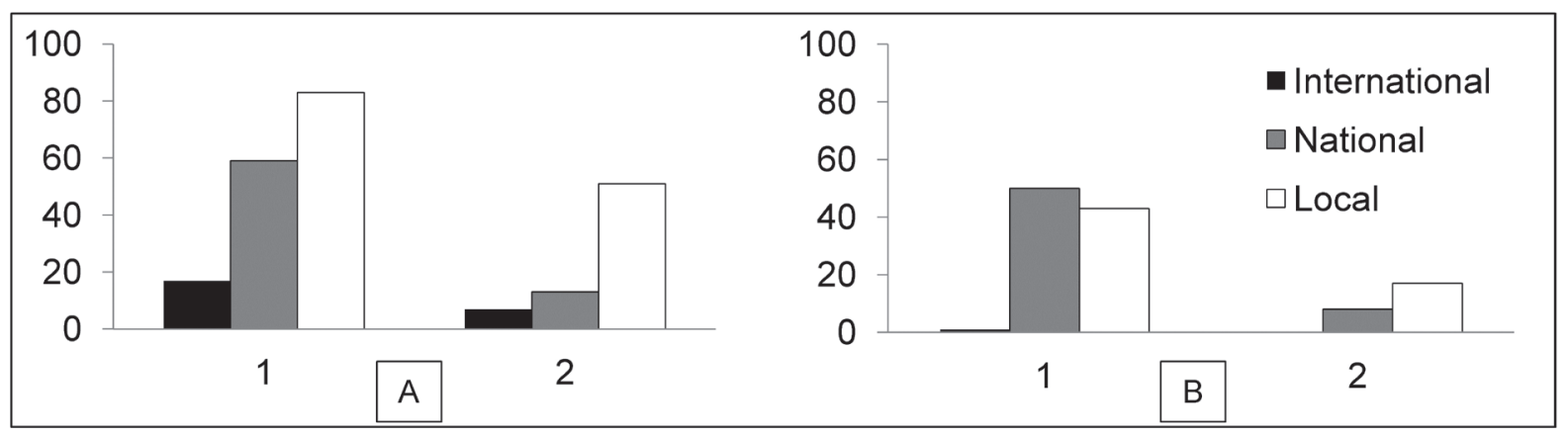

Figure 4. (A1) Number of documents according to the geographic scope of the study and (A2) number of papers according to the geographic scope of the study. (B1) Number of Mexican documents according to the scope of the study and (B2) number of Mexican papers according to the scope of the study.

\section{Case study: Mexico}

A total of 94 documents about Mexico were collected. Most of these documents reported studies performed at the national level (54\%) because many were developed by or for the Ministry of Environment and Natural Resources (SEMARNAT, for its Spanish acronym). As a federal institution it has a greater interest in studies performed at national level. In contrast, the collected scientific Mexican published researches mainly refer to studies conducted at the local level (65\%) (Figure 4B).

Great geographical contrast was observed among the 17 scientific Mexican papers describing local level studies (Table 3) and we found that the local "unit" is not uniform since it depends on the investigation objectives and scope.

Table 3. Scale of the study at the local level in the eleven analyzed Mexican published papers.

\begin{tabular}{lc}
\hline Scale of the study at the local level & $\begin{array}{c}\text { Number of } \\
\text { papers }\end{array}$ \\
\hline State & 3 \\
Protected natural area & 1 \\
Mexico City & 2 \\
Several communities & 5 \\
Communal land* & 2 \\
Village & 2 \\
Market & 1 \\
\hline
\end{tabular}

${ }^{*}$ ejido means a Mexican land tenure type.
Of the Mexico's documents, $73 \%$ represented grey literature comprised mostly of conference abstracts (Figure 5). Scientific findings are presented at congresses as preliminary results, and thus a congress presentation represents a method of communication that is brief, fast, less demanding, and of less responsibility and merit than an paper that is sent to a peer-reviewed journal (Olive et al. 2004). However, generally, in all scientific disciplines, a low percentage of the works that are presented at congresses are published, e.g., only $21 \%$ of the works presented at a specific congress were published in peer-reviewed journals (Olivé et al. 2004).

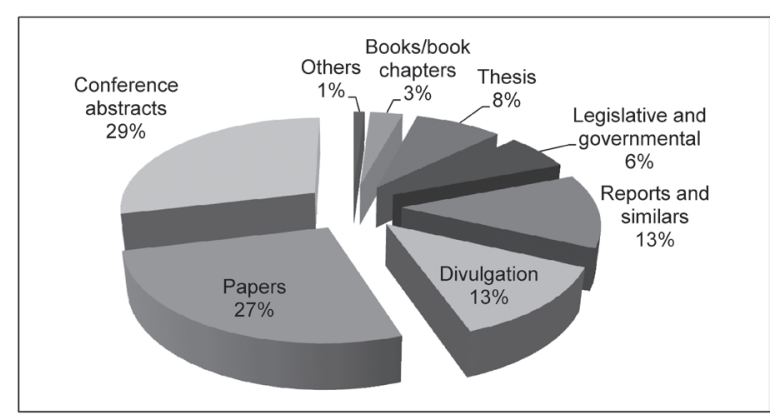

Figure 5. Mexican document $(\mathrm{N}=94)$ analysis by publication type. These are formed by 27 conference abstracts, 25 peer-reviewed papers, 12 divulgation papers, 12 reports and similar, 6 legislative and governmental documents, 8 thesis, 3 books or book chapters and one of other category. Conference abstracts and papers comprise more than half of total Mexican documents. 
A comparison of the research objectives of 25 Mexican published papers was performed in order to find how this pass-time the ethnoornithological research is being proposed. Overall, most of the papers are descriptive and provide lists of the utilized species. Nine of the papers describe hunting or the utilization of wild fauna in general, stressing the use of animals as food or medicine, though they indirectly may also mentioned their use as pets. Two of the studies (Arroyo-Quiroz et al. 2005; Sosa-Escalante 2011) evaluated the government strategies and other paper (Johnson et al. 2012) discloses a method to estimate the exploitation levels of passerines (Table 4).

Table 4. Research objectives of the analyzed Mexican published papers.

\begin{tabular}{|c|c|}
\hline General topic & Objective \\
\hline Agribusiness & $\begin{array}{l}\text { To describe the different types and categories of agricultural business in Mexico, paying } \\
\text { special attention to the Environmental Management Units (UMAs) of the state of Sonora. }\end{array}$ \\
\hline \multirow{4}{*}{$\begin{array}{l}\text { Hunting and } \\
\text { utilization of wild } \\
\text { fauna at local } \\
\text { level }\end{array}$} & $\begin{array}{l}\text { To describe the hunting strategies or the species of wild fauna that are utilized and their } \\
\text { uses at Quintana Roo }(n=2) \text {, Campeche }(n=1) \text {, Chiapas }(n=1) \text { and Yucatan }(n=1) \text {. }\end{array}$ \\
\hline & $\begin{array}{l}\text { To compare the hunting activities of the Lacandon, the Tzeltal, and the Mestizo people in } \\
\text { five communities to study subsistence hunting and to suggest appropriate conservation } \\
\text { tactics. }\end{array}$ \\
\hline & $\begin{array}{l}\text { To analyze the ways in which the inhabitants of the Natural Reserve of Sierra Nanchitla } \\
(n=1) \text { and the inhabitants of the neighbor community of a protected area in Tabasco }(n=1) \\
\text { use wild vertebrates. }\end{array}$ \\
\hline & To know the medicinal uses of wildlife in two ethnic groups of Chiapas. \\
\hline \multirow[t]{2}{*}{ Assay } & $\begin{array}{l}\text { Assay on the traffic of species in the world, in Latin America, in Mexico, and in Chihuahua } \\
\text { and on the routes and frontiers for the traffic of species, the environmental impact that } \\
\text { illegal traffic causes, and the role that both the Internet and environmental education play } \\
\text { in Mexico. }\end{array}$ \\
\hline & Assay about Mexican regulations related to wildlife trafficking. \\
\hline Case s & $\begin{array}{l}\text { To describe the case of Charco Cercado in San Luis Potosi as an example of the illegal } \\
\text { traffic of flora and fauna and to evaluate the success of the corresponding management } \\
\text { strategies and programs. }\end{array}$ \\
\hline \multirow[t]{2}{*}{$\begin{array}{l}\text { Methodological } \\
\text { design }\end{array}$} & $\begin{array}{l}\text { To develop methods to estimate the levels of sustainable exploitation of eleven Nearctic } \\
\text { passerines abiding by the market rules in Mexico. }\end{array}$ \\
\hline & To determine if one model can explain parrot trade in Mexico. \\
\hline \multirow{3}{*}{$\begin{array}{l}\text { Local utilization } \\
\text { of song and } \\
\text { ornamental birds }\end{array}$} & To report some of the species observed in captivity in Baja California. \\
\hline & $\begin{array}{l}\text { To determine the birds types that are most frequently used in Nuevo Leon and the reasons } \\
\text { for the existence of illegal practices. }\end{array}$ \\
\hline & $\begin{array}{l}\text { To list the birds that are found at the markets of the state of Mexico and Mexico City, to } \\
\text { describe their characteristics and the elements that make them attractive as pets and to } \\
\text { provide recommendations for their maintenance in captivity. }\end{array}$ \\
\hline \multirow{2}{*}{$\begin{array}{l}\text { Utilization of } \\
\text { birds of prey }\end{array}$} & To analyze the exploitation of birds of prey in Mexico. \\
\hline & $\begin{array}{l}\text { To register the falconiformes traded in Mexico City, to describe their characteristics and to } \\
\text { provide recommendations for their maintenance in captivity. }\end{array}$ \\
\hline $\begin{array}{l}\text { Utilization of } \\
\text { hummingbirds }\end{array}$ & $\begin{array}{l}\text { To list the species of hummingbirds traded at a market of Mexico City as well as their } \\
\text { medical uses. }\end{array}$ \\
\hline \multirow{4}{*}{$\begin{array}{l}\text { Utilization and } \\
\text { conservation of } \\
\text { parrots }\end{array}$} & To describe the exploitation of parrots in Mexico. \\
\hline & $\begin{array}{l}\text { To enlist the parrots that are traded in three markets close to Mexico City, to describe their } \\
\text { characteristics and to provide recommendations for their maintenance in captivity. }\end{array}$ \\
\hline & To evaluate the Yellow-headed Parrot (Amazona oratrix) distribution. \\
\hline & $\begin{array}{l}\text { To describe the captive breeding and reintroduction projects of the Scarlet Macaw (Ara } \\
\text { macao) in Mexico. }\end{array}$ \\
\hline
\end{tabular}


The methodology applied in the analyzed Mexican published papers was a combination of techniques characteristic of both natural and social sciences: transect sampling, modeling, registration of the resource users, documental investigation, analysis of the permits and seizures conducted by the authorities, interviewing, and direct and participant observation (Table 5). Participant observation and interviewing are the most frequently applied techniques in qualitative research and in social sciences (Taylor \& Bogdan 1984), and at the same time, these techniques have also been used very frequently in ethnobiology (Firme 2013). However, a deeper analysis of the observed techniques reveals that most of them generate quantitative information. Thus, these techniques are used to create lists of the utilized fauna through interviews or through observation at markets or by walks with the wild-fauna poachers. In fact, only two papers focusing on hunting (Quijano-Hernández \& Calmé 2002; Ramírez Barajas \& Naranjo 2007) used, in greater or lesser extent, an epistemological interpretive approach or an approach to social perception. This approach allows us to understand the reasons and beliefs that promote people's actions (Taylor \& Bogdan 1984), something that we consider fundamental for attaining a sound management of bird resources.

Table 5. Techniques utilized in the analysis of Mexican published papers. More than one technique could be used per paper.

\begin{tabular}{|c|c|c|}
\hline Type of approach & techniques & $\begin{array}{c}\text { Number of papers } \\
\text { that use this } \\
\text { approach }\end{array}$ \\
\hline \multirow{6}{*}{+ Social } & Interviewing the actors & 13 \\
\hline & Observation during the trade or the capture & 11 \\
\hline & Documental investigation & 8 \\
\hline & Quantitative analysis of the issued permits & 4 \\
\hline & Recording of the hunting data by the hunters & 1 \\
\hline & Seizures and confiscations by the authorities & 1 \\
\hline \multirow{2}{*}{$\begin{array}{c}\downarrow \\
+ \text { Biological }\end{array}$} & Eco-mathematical or geographical models & 2 \\
\hline & Transect sampling of the birds' populations & 1 \\
\hline
\end{tabular}

The main results obtained from the analysis of Mexican published papers were the following:

The Wildlife Conservation Management Units (UMA) are, according to Retes López and collaborators (2010), an example of the new type of agribusiness. The authors explain why the number of these units has increased in the country (e.g., from 2000 to 2009, the registered UMA increased from 3,531 to 9,141 ). In addition, the authors list the most frequently used species at game ranches in the state of Sonora and compare the corresponding economic profits with those generated by cattle ranches.

Eight papers address local hunting in villages located in Quintana Roo, Yucatan, Campeche, Chiapas, and the State of Mexico (Table 4). In these papers, it is mentioned that most of the biomass of the captured vertebrates is attributable to mammals (Naranjo et al. 2004; Ramírez Barajas \& Naranjo 2007) and that the reasons for hunting and capturing wild fauna were as follows: (1) to consume proteins, (2) to reduce crop and domestic animal damages, (3) to use wild animals in traditional medicines, and (4) to use wild animals as pets or for ornamental purposes. Although the general purpose of these eight studies is to study "all" of the wildlife, they focused on mammals, and one of the studies (Ramírez Barajas \& Naranjo 2007) even mentioned that it was not possible to identify smaller fauna, in which song and ornamental birds might have been found. Among the birds that could be reported in these researches, there 
are five species of parrots: Amazona albifrons, $A$. xantholora, A. oratrix, A. auropalliata, and Aratinga astec (Barrasa García 2013; Hernández-López et al. 2013, Quijano-Hernández \& Calmé 2002), and species of the families Columbidae and Phasianidae (Monroy-Vilchis et al. 2008), but the latter are used as a source of proteins. Finally, another species used as ornament was registered: the bird of prey Accipiter sp., the Toucan Ramphastos sulfuratus and the family Columbidae (Hernández- López et al. 2013; Monroy-Vilchis et al. 2008; Santos-Fita et al. 2012).

Garza Almanza (2008), in an assay, describes the trafficking of species throughout the world and in Latin America in particular, where the author focuses on Mexico and, specifically, in the state of Chihuahua. This author also reports the routes utilized for trafficking and the role of the Internet in this activity. Arroyo-Quiroz and collaborators (2005) describe and discusses public policy concerned with wildlife trafficking in Mexico, with special emphasis on CITES. The work by Sosa-Escalante (2011) mainly explains how the authorities acted against the illegal trade of wild fauna in Charco Cercado, located in the state of San Luis Potosi. It was demonstrated that legal permits are used to illegally trade for other birds (different from those provided by the permits), and a total of 32 different bird species were documented throughout the studied period (32 years). Pires \& Clarke (2012) results show that parrot poaching in Mexico is an opportunistic activity. Johnson and collaborators (2012) obtained, through models, population parameters of various species that are used as song and ornamental birds and concluded that the levels of exploitation established by the Mexican government are between one and three times lower than the estimated levels. This work concludes with some recommendations for the resource managers and reminds the reader that these recommendations are made under great uncertainty because the study is based in a series of population estimations that were collected from the literature. Hamilton (2001) presents a list of the birds observed in shops and at zoological parks in different cities of Baja California during the period $1999-2000$. Among the most frequently observed species are the following: Gambels' quail (Callipepla gambelii), ruddy ground dove (Columbina talpacoti), tropical mockingbird (Mimus gilvus), white-collared seedeater (Sporophila torqueola), northern cardinal (Cardinalis cardinalis), house finch (Haemorhous mexicanus), and the buntings (Passerina amoena, P. cyanea, P. versicolor, P. leclancherii, and P. ciris).

Contreras Balderas et al. (2001) indicate that in the period 1988 - 1993, there was an increase in the number of issued fauna-harvesting permits. In this sense, the most frequently harvested species include mammals and certain birds, such as ducks and pigeons. They estimate that subsistence and illegal hunting doubles that of legal hunting, in addition to the fact that the game species involved are different. The authors comment that the trade of song and ornamental birds provides employment to approximately 3,400 families in Mexico, and they mention some species whose populations are being seriously affected by this practice. The authors indicate that there are no population studies for any of the 27 ornamental permitted species, and, in particular, they mention (1) that in the state Nuevo Leon, the jay species Cyanocorax yncas, Aphelocoma ultramarina and $A$. coerulescens are those that must be preferentially evaluated; (2) that the trade of northern cardinal (Cardinalis cardinalis) must be banned; and (3) that more studies have to be conducted on the northern mockingbird (Mimus polyglottos) and the brown-backed solitaire (Myadestes occidentalis) populations. The authors mention that on a nationwide scale, birds are the most affected group of animals, particularly two species of parrots: Amazona viridiginalis and $A$. ochrocephala, whose prices oscillate between US $\$ 90$ and $\$ 530$ in the national market. In the case of the city of Monterrey, 73 native and 19 exotic species were found to be traded, and $40 \%$ of the commerce is illegal. Other common species, such as the painted bunting (Passerina ciris), also stand out at the markets and on the street markets of Monterrey.

Gómez Álvarez and collaborators (2005a) found 35 species of Mexican birds and six introduced bird species at the markets and bazaars of the State of Mexico and Mexico City, and their common names, characteristics, and costs are 
reported in the corresponding work. Four species of pigeons (Columbidae) were registered, along with two of toucans (Ramphastidae), two of jays (Corvidae), four of the family Turdidae, three of the Mimidae, one of the Laniidae, two of the Ptilogonatidae, one of the Thraupidae, five of Cardinalidae, two of Emberizidae, four of Icteridae, and four of Fringilidae. The most expensive bird reported was the toucan (Ramphastos sulfuratus), with a price between US $\$ 90$ and US $\$ 280$, and the least expensive were the rock dove (Columba livia) and the house finch (Haemorhous mexicanus), which are traded for US\$1.4. The same author, in a second paper (Gómez Álvarez \& Reyes Gómez 2010), registered 655 specimens of seven different species of hummingbird at a market of Mexico City, among which Amazilia beryllina was the most common. All of the traders interviewed in this study indicated that the hummingbird is useful for love-attraction rituals and for fighting blood and heart diseases. The origin of the hummingbird is the center of Mexico, and their capture is achieved through the use of slingshots. The price of a live hummingbird ranges between US $\$ 28$ and US $\$ 94$, and dead, between US $\$ 3.7$ and US\$10, depending on the species. Finally, the same author (Gómez Álvarez et al. 2005b) reports that six species of parrots were registered at the markets, and mentions that the specimens are purchased as chicks. Some of the interviewed traders commented that they also breed some species such as the budgerigar (Melopsittacus undulatus) and the lovebird (Agapornis sp.). The authors report the sale prices of the registered species, among which yellow-headed parrot (Amazona oratrix) has the highest price (US\$140), which is stablished according to the "intelligence" level of each animal, determined by its capability to speak. Finally, this work reports some features for the maintenance and feeding in captivity of each of the song and ornamental bird species.

Iñigo-Elias and Ramos (1991) also have a paper that specifically focuses on the utilization of parrots in Mexico in which they mention that between 1982 and 1983, the places where more parrots were legally captured were in the Pacific coast (Sinaloa, Nayarit, Jalisco and Oaxaca) and that the most frequently captured species were
Pionus senilis and Aratinga canicularis. The authors report the main capture methods, which include the collection of chicks from the nests and the use of nets and live bait. They also report that in the period between 1970 and 1982, a total of 133,299 parrots were exported from Mexico to the United States. The authors comment that the death toll during the trade is high: during the capture of chicks, approximately $10 \%$ of them die, depending on the species. The highest death toll $(30 \%)$ and occurs when parrots are confined in Mexico City. Additionally, the authors indicate that with the illegal traffic of parrots, this death toll increases up to $40-50 \%$. Finally, they mention that the prices of some of the parrot species (e.g. Ara macao) in a market in Mexico was US\$450, while in a shop in the USA, the price varied between US $\$ 2,000$ and US\$4,000. Two other papers deal with Psitacidae: Monterrubio et al. (2007) calculated the historic and current distribution of the Yellow-headed Parrot, and Raigoza Figueras (2014) explains in detail the reintroduction program of the Scarlet Macaw (Ara macao).

Lastly, two papers address the utilization of Falconiformes: Montesinos Pacheco and Cerecedo Palacios (2010) found a total of 872 specimens belonging to 29 species of birds of prey legally owned by 640 private owners in 22 states, and Gomez Álvarez and collaborators (2006) found eight birds of prey during six visits to a market of Mexico City.

According to the present analysis of Mexican published papers, it may be observed that, as in the rest of the Latin American works, most of the papers are of descriptive character, i.e., many of them exclusively provide lists of the utilized species.

The journals where Mexican papers were published do not have an impact factor or it is very low (Table 6). In fact, only Ecological Applications has a relatively high impact factor (2013: 4.126). 
Table 6. Journals where Mexican papers were published.

\begin{tabular}{|c|c|}
\hline Journals & Papers \\
\hline $\begin{array}{l}\text { Ciencia UANL (Autonomous University } \\
\text { of Nuevo Leon) }\end{array}$ & 1 \\
\hline CULCyT (Cultura, Ciencia y Tecnología) & 1 \\
\hline Ecological Applications & 1 \\
\hline El canto del Centzontle & 2 \\
\hline Etnobiología & 4 \\
\hline Interciencia & 2 \\
\hline International ZooYearbook & 1 \\
\hline Journal of Ethnobiology & 1 \\
\hline Journal of Ethnobiology & 1 \\
\hline $\begin{array}{l}\text { Journal of Ethnobiology and Ethno- } \\
\text { medicine }\end{array}$ & 1 \\
\hline $\begin{array}{l}\text { Journal of International Wildlife Law \& } \\
\text { Policy }\end{array}$ & 1 \\
\hline $\begin{array}{l}\text { Journal of Research in Crime and Delin- } \\
\text { quency }\end{array}$ & 1 \\
\hline Monographs in Field Ornitology & 1 \\
\hline Ornitología Neotropical & 1 \\
\hline Ra Ximhai & 1 \\
\hline $\begin{array}{l}\text { Revista AMMVEPE (from the Mexican } \\
\text { association of Veterinary Doctors Spe- } \\
\text { cialists in Small Species) }\end{array}$ & 3 \\
\hline Revista Mexicana de agronegocios & 1 \\
\hline Therya & 1 \\
\hline
\end{tabular}

The objectives of the conference proceedings were the gathering of information regarding the utilized species and their uses in specific regions of the country. Their results indicate that species of the families Cardinalidae, Psitacidae and Columbidae are utilized in a variety of manners, from the ornamental to the nutritional. Similar to the techniques utilized in the analysis of Mexican published works, the techniques most frequently applied in these studies were interviewing and surveying and, to a lesser degree, observation at the markets and documental analysis.

Divulgation papers largely tried to disclose wildlife exploitation, and most of these works focused exclusively on parrots. In some of these documents, a scene of how this exploitation is regulated or has been regulated throughout recent history through, e.g., UMA, is provided; others include information on the natural history of the utilized species and how their exploitation negatively influences the species. Some documents offer management proposals for this practice; in one document, it is mentioned that the Emberizidae is the most exploited family in the country. None of these documents explains how the information was gathered. One of the well-known authors in the divulgation of information concerning the exploitation of parrots is Juan Carlos Cantú (1997; 2007; 2011), who argues that in Mexico, there is no interest in the captive breeding of parrots because there are not enough aviaries dedicated to this activity. In general, these papers are mixed, and they provide an overview of the practice without providing robust data. However, they are very useful to come up with scientific questions and to promote the development of new studies.

The main objectives and results of three books or book chapters were the following. (1) To share how the exploitation (capture, harvest, transportation, quarantine, and trade) of $S$ and $O$ birds is conducted in Mexico and to explain, with the aid of data from related literature and legislation (issued permits), the associated problems. (2) To describe, through the presentation of UMA lists and the exploitation rates of five species of parrots during the period $2000-2008$, the current situation of the exploitation of $\mathrm{S}$ and $\mathrm{O}$ species in the state of Campeche. In this case, it is also mentioned that, although the exploitation of Cardinalis cardinalis, Carduelis psaltria and the genera Icterus is not permitted, it is common to see these animals in homes, and thus it is suggested to apply the law as well as to increase vigilance and to establish appropriate internal control. (3) Finally, to review how the trade of birds from the wilderness is dealt with and (a) the schedules under which it is possible to accomplish the sustainable exploitation of these species, (b) the main field techniques and the mathematical algorithms needed to determine the volume of the captures, and (c) the steps needed to approve the management plans that guarantee sustainability and the corresponding exploitation rates.

The main subject of the analyzed thesis were about wildlife in local study areas, and only two thesis were exclusively about birds use (Table 7). 
Table 7. Titles of the collected thesis, ordered from the most general to the most specific.

\section{Thesis' topics}

\begin{tabular}{c|l}
\hline 1 & $\begin{array}{l}\text { The judicial framework for the protection of } \\
\text { wildlife in the face of the international illegal } \\
\text { commerce. }\end{array}$ \\
\hline 2 & $\begin{array}{l}\text { The illegal traffic of wild species: Ioss } \\
\text { of biodiversity and the international } \\
\text { accountability. }\end{array}$ \\
\hline 3 & $\begin{array}{l}\text { Traffic and illegal trade of endangered fauna } \\
\text { since the establishment of ClTES (Convention } \\
\text { on International Trade in Endangered Species } \\
\text { of Wild Fauna and Flora). }\end{array}$ \\
\hline 4 & $\begin{array}{l}\text { Juridical analysis of the illegal trade of } \\
\text { endangered wildlife in the state of Mexico. }\end{array}$ \\
\hline 5 & $\begin{array}{l}\text { Current situation of the illegal traffic and } \\
\text { wildlife trade in the state of Chihuahua. }\end{array}$ \\
\hline 6 & $\begin{array}{l}\text { Environmental management and local wildlife } \\
\text { use in a Campeche protected area. }\end{array}$ \\
\hline 7 & $\begin{array}{l}\text { Song and ornamental birds trade evaluation in } \\
\text { Mexico 1970 - 2001. }\end{array}$ \\
\hline 8 & $\begin{array}{l}\text { Song and ornamental bird trade in the } \\
\text { metropolitan area of Monterrey, Nuevo Leon, } \\
\text { Mexico. }\end{array}$ \\
\hline
\end{tabular}

The reports were organized in two groups: one group comprising those generated by nongovernmental organizations (NGO) and another comprising those generated by the governmental sector or generated by government request. The three reports that NGO generated had the following objectives: (1) to collect the existing information about wildlife exploitation in Mexico (Traffic), (2) to describe the parrot exploitation from a non-sustainability perspective (Cantú et al. 2007), and (3) to compare birdwatching with bird harvest (Cantú et al. 2011). The reports generated by the government sector included the following: two wildlife guides; one wildlife conservation program; a wildlife national strategy program; and a conservation project for management and exploitation of parrots. In addition, these reports included two workshop summaries: a workshop on the conservation and utilization of wild birds and mammals at UMA and a workshop on the conservation and sustainable utilization of parrots in Mexico. Finally, a work requested by the government on the economic importance of wild vertebrates of Mexico.

Lastly, a series of legislative documents, which comprise the Federal Criminal Code, two laws, one regulation, one manual, and a standard management plan, are also described (Table 8). The General Law of Ecological Balance and Environmental Protection [Ley General del Equilibrio Ecológico y la Protección al Ambiente -LGEEPA, for its name and initials in Spanish] addresses the protection of the environment in the national territory, among other topics. The objective of this law is to favor sustainable development and to establish the basis for, among other issues, (1) defining the principles of an environmental science policy and the instruments for its application, (2) the preservation and protection of biodiversity, and (3) a sustainable exploitation so that the acquirement of economical profits might be compatible with those activities aimed at preserving the ecosystems. The objective of the General Wildlife Law is to establish concord among the Federal Government and the State and Districts governments, in the scope of their respective competences, for the conservation and sustainable exploitation of wildlife and its habitat. Lastly, the Standard Management Plan of Song and Ornamental Birds is a technical document elaborated by the DGVS to homogenize the development of the activities of UMA with respect to the conservation, management and sustainable exploitation of song and ornamental birds (Definition in the Regulation of the General Wildlife Law).

Table 8. Collected Mexican legislative documents.

\begin{tabular}{l|l}
\hline 1 & Federal Criminal Code. \\
\hline 2 & $\begin{array}{l}\text { General Law of Ecological Balance and } \\
\text { Environmental Protection (LGEEPA). }\end{array}$ \\
\hline 3 & General Wildlife Law. \\
\hline 4 & Regulation of the General Wildlife Law. \\
\hline 5 & $\begin{array}{l}\text { Manual of the procedures for the } \\
\text { authorizations, permits, registrations, reports, } \\
\text { and notices related to the conservation, } \\
\text { management, and sustainable wildlife } \\
\text { exploitation and other biological resources. }\end{array}$ \\
\hline 6 & $\begin{array}{l}\text { Standard Management Plan of Song and } \\
\text { Ornamental Birds. }\end{array}$ \\
\hline
\end{tabular}




\section{CONCLUSIONS}

In this review, we demonstrated that most of the existing information on the exploitation of live birds is found as grey literature. We found that in Latin America and in Mexico as well, the literature about the ethnobiology of bird-keeping is descriptive in general. We did not find a significant difference between the type and manner of research in Mexico and in the rest of Latin America. Countries where more research is done are Brazil and Mexico. One of the main differences in the subject matter observed between these two countries is their regulation system: although in Brazil birds' trade as pets is forbidden, in Mexico, there is some regulation of this issue. Thus, we observe that in Mexico, there is a variety of information published on how to accomplish sustainable exploitation of song and ornamental birds. With respect to this topic, it must be stressed that in Mexico in particular, and at the international level in general, there are two contradictory opinions: one that favors the authorization of the sustainable exploitation of song and ornamental birds and another that favors the prohibition of such exploitation and the application of strict vigilance. This discussion remains on the table. With respect to the languages used for publishing, Spanish was the most frequently used language across the collected literature, whereas English was the most common in peer-reviewed papers. Accordingly, it is important to emphasize that when a Latin American bibliography search is conducted, it is necessary to take into account both Latin American journals and international journals because very valuable information would otherwise be lost (Thatje et al. 2007). A great deal of the available information on the utilization of birds as pets is included in studies focused on wild fauna or wild birds, and there are few studies that focus exclusively on song and ornamental birds. This circumstance reflects a lack of research exclusively focused on the trade of birds as pets, and thus new lines of research on this topic should be developed.

Most of the Latin American research provides lists of bird species utilized and their corresponding uses, mainly at a local level. Half of the studies were conducted through an interdisciplinary approach by using techniques that belong to the social sciences, such as interviewing, participant observation during capture or trade, and direct observation at the markets. Unfortunately, the interpretative or the social perception approaches are very rarely used. At the same time, our initial assumption that parrots are the most representative subjects of study in the Latin American and Mexican scientific papers was confirmed.

It is imperative that further research in Latin America and, particularly, in Mexico, be conducted on the trade of birds different from the Psittacidae to determine the causes that motivate their use and the corresponding ecological and social consequences. We conclude that a greater effort for the development of socio-economic studies and, specially, as mentioned by Argueta Villamar and collaborators (2012), of studies on the perception of the actors involved in the exploitation of the resources is necessary. In this last sense, it is important to focus on the perception of the direct users, which are the poachers, the traders, and the buyers of live wild birds, so that the regulation efforts provide real benefits and so that alternatives might be proposed to the users of the most endangered resources.

Finally, we want to mention that in this paper we leave aside the search and review of popular and cultural literature related with bird keeping. Therefore an additional work could be to expand the scope of the review through the search and analysis of anthropological texts and cultural histories and/or include a wider review of popular literature in Latin America, for example magazines, handbooks, field guides and web-pages as it was similarly done by Jepson and Ladle (2009) in Indonesia.

\section{ACKNOWLEDGEMENTS}

We thank the collaboration and the several advise coming from Mexican ornithologist from yahoo groups' ornitologica de Mexico and Sociedad para el Estudio y Conservación de las Aves en México A.C. (CIPAMEX). Consejo Nacional 
de Ciencia y Tecnología (CONACyT) provided funding for this work. Thanks are also owed to two anonymous reviewers for helpful suggestions and comments.

\section{REFERENCES}

1. Abensperg-Traun M (2009) CITES, sustainable use of wild species and incentive-driven conservation in developing countries, with an emphasis on southern Africa. Biological Conservation 142:948-963

2. Alacs $E$, Georges $A$ (2008) Wildlife across our borders: a review of the illegal trade in Australia. Australian Journal of Forensic Sciences 40:147-160

3. Albuquerque UP (2013) How to improve the quality of scientific publications in ethnobiology. Ethnobiology and Conservation 2:1.5

4. Alves RRN, Nogueira E, Araujo H, Brooks S (2010) Bird-keeping in the Caatinga, NE Brazil. Human Ecology 38 (1):147-156

5. Alves RRN, Lima JRF, Araújo HF (2013) The live bird trade in Brazil and its conservation implications: an overview. Bird Conservation Internationa/ 23 (01):53-65

6. Alves RRN, Leite RC, Souto WMS, Bezerra DMM, Loures-Ribeiro A (2013) Ethno-ornithology and conservation of wild birds in the semi-arid Caatinga of northeastern Brazil. Journal of Ethnobiology and Ethnomedicine 9 (1):14

7. Argueta Villamar A, Corona-M E, Alcántara-Salinas G, SantosFita D, Aldasoro Maya EM, Serrano Velázquez R, Teutli Solano C, Astorga-Domínguez M (2012) Historia, situacción actual y perspectivas de la etnozoología en México. Etnobiología 10:18-40

8. Arroyo-Quiroz I, Perez-Gil R, Leader-Williams N (2005) Developing countries and the implementation of CITES: The Mexican experience. Journal of International Wildlife Law and Policy 8:13-49

9. Barrasa García (2013) Conocimiento y usos tradicionales de la fauna en dos comunidades campesinas de la Reserva de la Biosfera de la Encrucijada, Chiapas. Etnobiología 10(1):16-28

10. Barbosa JAA, Nobrega VA, Alves RRN (2010) Aspectos da caça e comércio ilegal da avifauna silvestre por populações tradicionais do semi-árido paraibano. Revista de Biologia e Ciencias da Terra 10:39-49

11. Beissinger SR, Bucher EH (1992) Can parrots be conserved through sustainable harvesting? BioScience 42:164-173

12. Bezerra DMMSQ, Araujo HFP, Alves RRN (2011) The use of wild birds by rural communities in the semi-arid region of Rio Grande do Norte State, Brazil. Bioremediation, Biodiversity and Bioavailability 1:117-120

13. Bezerra DMM, Araujo HFP, Alves RRN (2012) Captura de aves silvestres no semiárido brasileiro: técnicas cinegéticas e implicações para conservação. Tropical Conservation Science 5 (1):50-66

14. Bird Trade SC of the AOU Conservation Cmte. (1991) The conservation crisis: international trade in live exotic birds creates a vast movement that must be halted. Auk (American Ornithologists Union) 108:982

15. Briceño-Linares JM, Rodríguez JP, Rodríguez-Clark KM, RojasSuárez F, Millán PA, Vittori EG, Carrasco-Muñoz M (2011) Adapting to changing poaching intensity of yellow-shouldered parrot (Amazona barbadensis) nestlings in Margarita Island, Venezuela. Biological Conservation 144:1188-1193

16. Bush ER, Baker SE, Macdonald DW (2014) Global Trade in Exotic Pets 2006-2012. Conservation Biology 28:663-676

17. Cantú JC, Sánchez Saldaña ME, Grosselet M, Silva Gámez J (2007) Tráfico ilegal de pericos en México, una evaluación detallada. Defenders of Wildlife, Washington D.C.

18. Cantú JC (1997) Normatividad y comercio de psitacidos en Mexico. Calidad Ambienta/ 3:4-7

19. Cantú JC, Gomez de Silva H, Sánchez ME (2011) El Dinero Vuela. El Valor Económico del Ecoturismo de Observación de Aves. Defenders of Wildlife, Washington

20. Collar NJ (1992) Threatened Birds of the Americas. International Council for Bird Preservation, International Union for Conservation of Nature and Natural Resources. Smithsonian Institution Press in cooperation with International Council for Bird Preservation, Business \& Economics

21. Contreras Balderas, AJ, García Salas JA, Guzmán Velasco A, González Rojas JI (2001) Aprovechamiento de las aves cinegéticas, de ornato y canoras de Nuevo León, México. Ciencia UANL (Universidad Autónoma de Nuevo León) IV:462-470

22. Desenne P, Strahl SD (1991) Trade and the conservation status of the family Psittacidae in Venezuela. Bird Conservation International 1:153-169

23. Diario Oficial de la Federación DOF (2010) NOM-059-ECOL-2010. Norma Oficial Mexicana

24. Fernandes G, Caparroz R. 2013. DNA sequence analysis to guide the release of blue-and-yellow macaws (Ara ararauna, Psittaciformes, Aves) from the illegal trade back into the wild. Molecular Biology Reports 40:2757-2762

25. Fernandes-Ferreira $\mathrm{H}$, Mendonça SV, Albano C, Ferreira FS, Alves RRN (2010) Comércio e criação de aves silvestres (Psittaciformes, Piciformes e Passeriformes) no Estado do Ceará. In: Alves RRN, Souto WMS, Mourão JS (eds) A Etnozoologia no Brasil: importância, status atual e perspectivas futuras NUPEEA, Recife, pp 381-402

26. Fernandes-Ferreira H, Mendonça SV, Albano C, Ferreira FS, Alves RRN (2012) Hunting, use and conservation of birds in Northeast Brazil. Biodiversity and Conservation 21:221-244

27. Firme, RP (2013) Disciplines: Ethnobiology. Indiana University [http://www.indiana.edu/ wanthro/theory_pages/ethnobio.htm] Accessed 5 September 2013

28. Gama TP, Sassi R (2008) Aspectos do comércio ilegal de pássaros silvestres na cidade de João Pessoa, Paraíba, Brasil. Gaia Scientia 2:1-20

29. Garza Almanza V (2008) Trafico ilegal de vida silvestre y educación ambiental CULCYT (Cultura, Ciencia y Tecnología) 5:5-12

30. Gobbi J, Rose D, De Ferrari G, Sheeline L (1996) Parrot smuggling across the Texas-Mexico border. Traffic USA, Washington D.C.

31. Godoy SN, Matushima ER (2010) A survey of diseases in passeriform birds obtained from illegal wildlife trade in Sao Paulo City, Brasil. Journal of Avian Medicine and Surgery 24:199209

32. Gómez Álvarez G, René Reyes S, Valadez Azúa R (2006) Falconoformes Mexicanas, comercio y uso en la cetrería. AMMVEPE (Asociación Mexicana de Médicos Veterinarios Especialistas en Pequeñas Especies, A.C.) 17:245-254 
33. Gómez Álvarez G, Reyes Gómez SR (2010) Colibríes comercializados como productos medicinales en el Distrito Federal, México. El canto del Centzontle 1:103-108

34. Gómez Álvarez G, Teutli Solano C, Reyes Gómez SR, Valadez Azúa $R$ (2005a) Pajaros y otras aves ulilizados como animales de ornato y compañía. AMMVEPE (Asociación Mexicana de Médicos Veterinarios Especialistas en Pequeñas Especies, A.C.) 16:129-139

35. Gómez Álvarez G, Valadez Azúa R, Teutli Solano C, Reyes Gómez SR (2005b) Manejo en cautiverio de psitácidos utilizados como aves de ornato y compañía AMMVEPE (Asociación Mexicana de Médicos Veterinarios Especialistas en Pequeñas Especies, A.C.) 16:5-17

36. Hamilton RA (2001) Records of caged birds in Baja California. Monographs in Field Ornithology 3:254-257

37. Hernández-López A, López-Alamilla E, Rodríguez Ramírez $A$, Aquino-Bravata V. Diagnóstico del uso de la fauna silvestre, en el área de protección de flora y fauna "Cañón del Usumacinta", Tenosique Tabasco. Ra Ximhai 9 (1):1-13

38. Herrera M, Hennessey B (2008) Monitoring Results of the illegal parrot trade in the los pozos market, Santa Cruz dela Sierra, Bolivia. Partners in Flight Conference: Tundra to Tropics 232-234

39. Iñigo-Elias EE (1983) The trade in diurnal birds of Prey in Mexico. Birds of Prey Bulletin 3

40. Iñigo-Elias EE, Ramos MA (1991) The Psittacine trade in Mexico. In: Robinson JG, Redford KH (eds) Neotropical wildlife use and conservation. The University of Chicago Press, Chicago and London, pp. 129-132

41. Jepson P, Ladle RJ (2009) Governing bird-keeping in Java and Bali: evidence from a household survey. Oryx 43:364-374

42. Johnson FA, Walters MAH, Boomer GS (2012) Allowable levels of take for the trade in nearctic songbirds. Ecological Applications 22:1114-1130

43. Juniper (2002) Spix's Macaw: The Race to Save the World's Rarest Bird. Washington Square Press. New York

44. Lacanilao $F(1997)$ Continuing problems with gray literature* Environmental Biology of Fishes 49:01-05

45. Licarião MR, Bezerra DMM, Alves RRN (2013) Wild birds as pets in Campina Grande, Paraíba State, Brazil: An Ethnozoological Approach. Anais da Academia Brasileira de Ciências 85 (1): 201213

46. López-Medellín X (2003) Evaluación del comercio de aves canoras y de ornato en México 1970-2001. Thesis, Universidad Nacional Autónoma de México, México, D.F.

47. López-Medellín X, \& Iñigo-Elias EE (2009) La captura de aves silvestres en México: Una tradición milenária y las estrategias para regularla. Biodiversitas $83: 11-15$

48. Marín-Espinoza G, Guevara-Vallera S, Prieto-Arcas A, MuñozGil J, Carvajal-Moreno Y (2011) Comercialización ilegal de aves silvestre: un caso en Venezuela. The Biologist (Lima) 9:38-52

49. Monroy-Vilchis O, Cabrera L, Suárez P, Zarco-González MM, Rodríguez-Soto C, Urios V (2008) El uso tradicional de vertebrados silvestres en la Sierra Nanchititla, México. Interciencia 33:308313

50. Monterrubio-Rico TC, Villaseñor-Gómez LE, Marin-Togo MC, López-Cordova EA, Fabian-Turja B, Sorani-Dalbon V (2007) Historical and cuttern distribution of the Yellow-headed Parrot (Amazona oratrix) on the central pacific coast of Mexico: Advantages and limitations in the use of GARP for species under strong traffic pressure. Ornitologia Neotropical 18:263-276
51. Montesinos Pacheco El, Cerecedo Palacios G (2010) Situación actual del aprovechamiento de aves rapaces en Mexico. El canto del Centzontle 1:75-88

52. Naranjo E, Guerra MM, Bodmer RE, Bolaños JE (2004) Subsistence hunting by three ethnic groups of Lacandon Forest, Mexico. Journal of Ethnobiology 24:233-253

53. Olivé A, Cifuentes I, Corbacho DV, Roca J (2004) Rumbo a lo desconocido: destino final de los resúmenes presentados a un congreso de reumatología. Revista Española de Reumatología 31:122-125

54. Onofri Saiki PT, Estevinho Guido LdF, de Oliveira Cunha AM (2009) Ethno-ecology, ethno-taxonomy and cultural value of psittacidae in rural districts of the triângulo mineiro region, Brazil. Revista Brasileira de Ornitologia 17(1):41-52

55. Phillips O, Gentry AH, Reynel C, Wilkin P, Galvez-Durand BC (1994) Quantitative Ethnobotany and Amazonian Conservation. Conservation Biology 8:225-248

56. Pires S, Clarke RV (2012) Are Parrots CRAVED? An Analysis of Parrot Poaching in Mexico. Journal of Research in Crime and Delinquency 49:122-146

57. Quijada $F(2008)$ Revistas científicas e indices de impacto. A propósito de "Hacer saber". Área abierta 20:1-10

58. Quijano-Hernández E, Calmé S (2002) Patrones de cacería y conservación de la fauna silvestre en una comunidad maya de Quintana Roo, México. Etnobiología 2:1-18

59. Ramírez Barajas PJ, Naranjo E (2007) La cacería de subsistencia en una comunidad de la zona maya, Quintana Roo, Mexico. Etnobiología 5:65-85

60. Regalado A (2010) Brazilian Science: Riding a Gusher. Science, Newsfocus. Pages 1306-1312

61. Regueira RFS, Bernard E (2012) Wildlife sinks: Quantifying the impact of illegal bird trade in street markets in Brazil. Biological Conservation 149:16-22

62. Retes López R, Cuevas González MI, Moreno Medina S, Denogean Ballesteros FG,. Ibarra Flores F, Martín Rivera M (2010) Unidad de Manejo para la conservación de la vida silvestre como alternativa para los nuevos agronegocios. Revista Mexicana de Agronegocios 27:336-346

63. Reuter A, Mosig P (2010) Comercio y aprovechamiento de especies silvestre en México: observaciones sobre la gestión, tendencias y retos relacionados. Traffic

64. Rocha MSP, Cavalcanti PCM, Sousa RL, Alves RRN (2006) Aspectos da comercialização ilegal de aves nas feiras livres de Campina Grande, Paraíba, Brasil. Revista de Biologia e Ciências da Terra 6 (2):204-221

65. Sahagún FBd (1969) Historia general de las cosas de nueva España, 2a ed. numeración, anotaciones y apéndices de Ángeles María Garibay K, Porrúa, México

66. Santos-Fita D, Naranjo E, Rangel-Salazar J (2012) Wildlife uses and hunting patterns in rural communities of the Yucatan Peninsula, Mexico. Journal of Ethnobiology and Ethnomedicine 8:1-17

67. Sarukhan J (2012) Capital natural de México: Acciones estratégicas para su valoración, preservación y recuperación. Comisión Nacional para el Conocimeinto y Uso de la Biodiversidad, México

68. Scarano FR (2007) Perspectives on biodiversity science in Brazil. Scientia Agricola 64:439-447 
69. Scarano FR, J. Silva MCD, Gumaraes AL, Raik D, Boltz F (2012) Brazil on the spot: Rio+20, sustainability and a role for science. Brazilian Journal of Botany 35:233-239

70. Sosa-Escalante (2011) Aplicación de la Ley para el combate del tráfico ilegal de vida silvestre en México: El caso de Charco Cercado. THERYA 2:245-262

71. Taylor SJ, Bogdan R (1984) Introducción a los métodos cualitativos de investigación. Paidós Ibérica, S.A. Barcelona, España

72. Thatje S, Laudien J, Heilmayer O, Nauen C. E (2007) Understanding El Niño - The importance of Grey Literature in Coastal Ecosystem Research and Management. Marine Policy 31:85-93

73. Thomsen JB, Edwards SR, Mullike TA (1991) Species in danger. Perceptions, conservation \& management of wild birds in trade. Traffic International

74. Valdez R, Guzmán-Aranda JC, Abarca FJ, Tarango-ArÁMbula LA, Sánchez FC (2006) Wildlife conservation and management in Mexico. Wildlife Society Bulletin 34:270-282

75. Weintraub I (2000) The role of grey literature in the sciences. [http://library.brooklyn.cuny.edu/access/greyliter.htm] Accessed: 3 August 2013

76. Weston MK, Memon MA (2009) The illegal parrot trade in latin america and its consequences to parrot nutrition, health and conservation. Bird Populations 9:76-83

77. Wright TF, Toft CA, Enkerlin-Hoefligh E, Gonzalez-Elizondo J, Albornoz M, Rodríguez-Ferraro A, Rojas-Suárez F, Sanz V, Trujillo A, Beissinger SR, Berovides VA, Gálvez XA, Brice AT, Joyner K, Eberhard J, Gilardi J, Koenig SE, Stoleson S, Martucelli, M. Meyers, K. Renton, A. M. Rodríguez, A. C. Sosa-Asanza, F. J. Vilella P, Wiley JW (2001) Nest poaching in Neotropical parrots. Conservation Biology 15:710-720 